ROBERT B. DOWNS

\title{
Doctoral Programs and Library Resources
}

$\mathrm{T}_{\mathrm{r}}$ HE ACCOMPANYING TABLE includes all United States institutions, which, according to American Universities and Colleges (9th edition, 1964), conferred five or more doctoral degrees during the period 1953-1962-a total of 186 universities, colleges, seminaries, institutes, and schools.

The tabulation presents the number of degrees awarded by each institution, and the figures are further broken down by broad fields: humanities, biological sciences, physical sciences, and social sciences. In a few instances, the total number of degrees is larger than the totals of the four subject fields, because the degrees were not classifiable by fields; in this category were "degrees in arts without major, sciences without major, and all others." The final two columns record for each library the number of volumes held and the total expenditures for books, periodicals, and binding in 1962, the final year covered by the decade of statistics of doctoral degrees.

The chief purpose of the present investigation is to determine whether there exists any direct correlation between the number and variety of doctoral degrees awarded and the strength of library resources in individual institutions.

A glance at the table, wherein institutions are arranged in order of the number of doctoral degrees conferred, will reveal a close relationship, in general, between degrees and library support.

Dr. Downs is Dean of Library Administration in the University of Illinois.
Among the thirty-seven universities which awarded more than seven hundred degrees each during the decade, only ten held less than one million volumes, and none possessed less than onehalf million volumes; two of the ten have gone past the million mark since 1962 . Of the thirty-six institutions reporting between three hundred and seven hundred degrees each, eighteen held collections in excess of five hundred thousand volumes, and two were over one million volumes; three others have gone above the one million figure since 1962 .

Approached in another way, of the 93,799 doctoral degrees awarded in the United States for the 1953-62 period, 58,150 , or nearly two-thirds, came out of the thirty universities with libraries containing more than one million volumes each.

Special factors should be noted in the cases of the two top degree-producing institutions: Columbia and California. Of Columbia's imposing total of 5,644 doctoral degrees, 3,438 were awarded by Columbia University proper and 2,206 by Teachers College. California's 5,024 degrees represented five different campuses, but chiefly Berkeley and Los Angeles, both owning multi-million volume libraries.

Book expenditures for the last year of the decade were more uneven than were the volume holdings. Among the fortyfour institutions awarding more than five hundred degrees each, the range was from Catholic University's $\$ 82,151$ to the combined University of Cali- 
TABLE 1

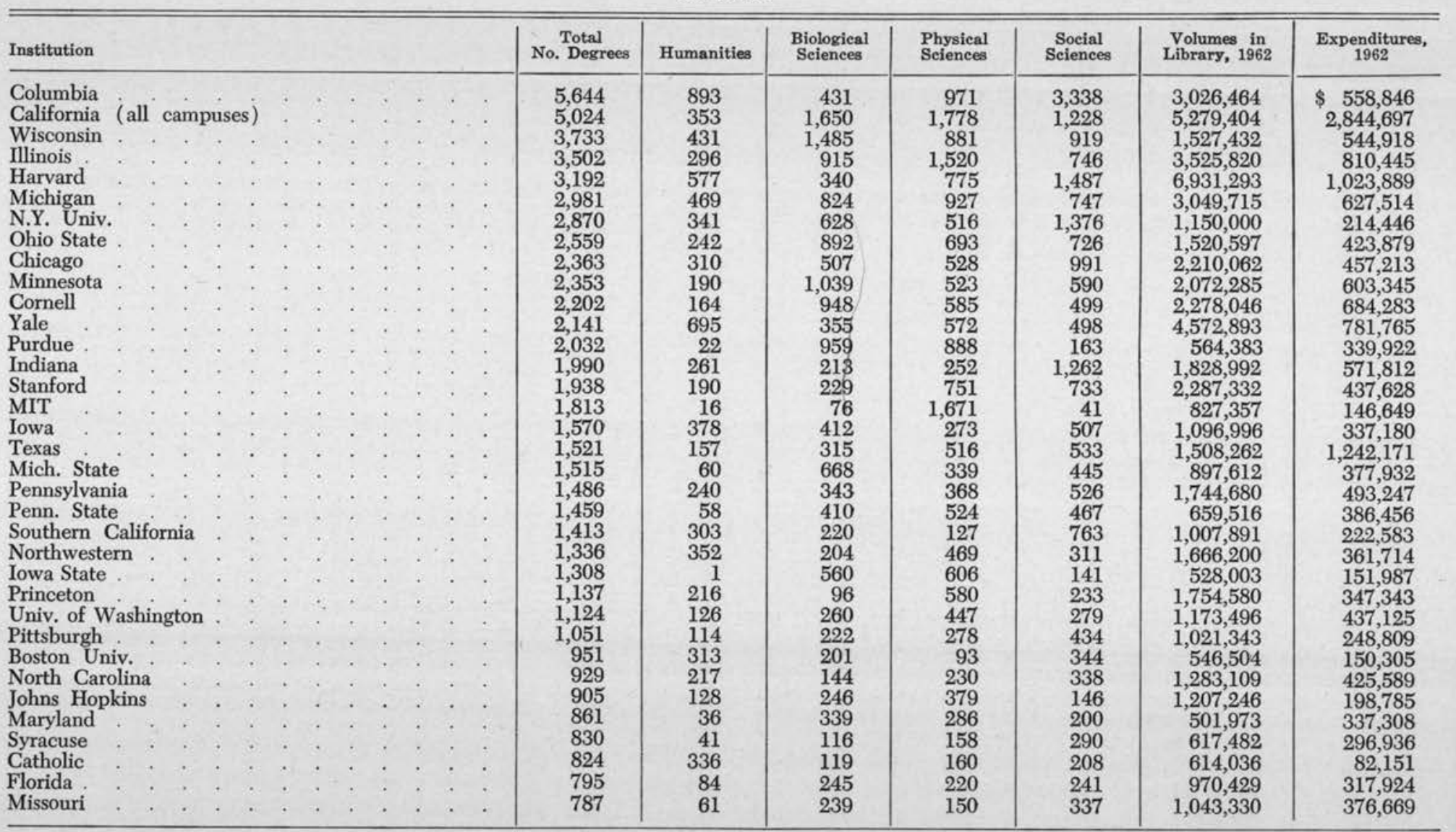




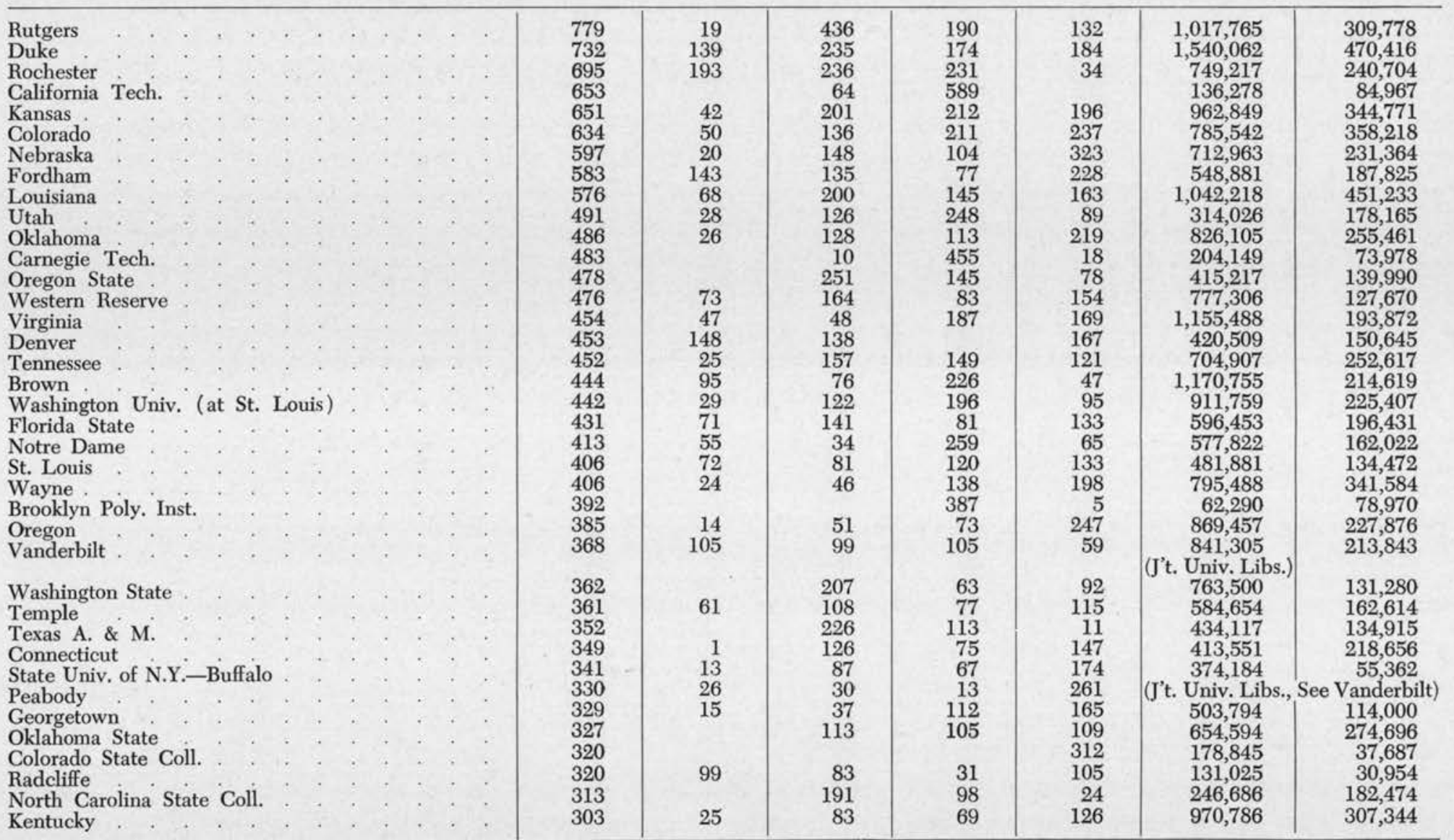


TABLE 1 (cont.)

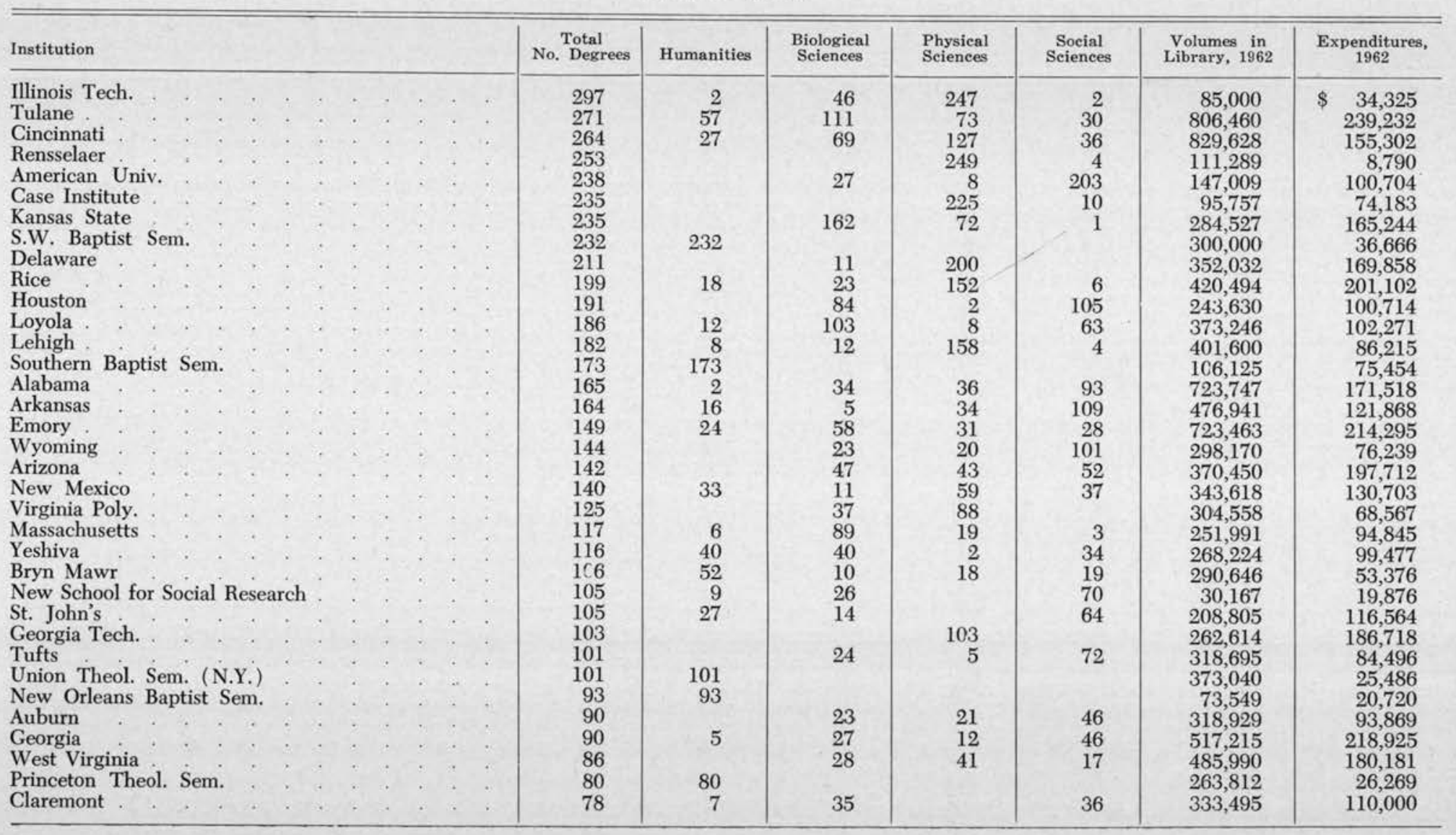




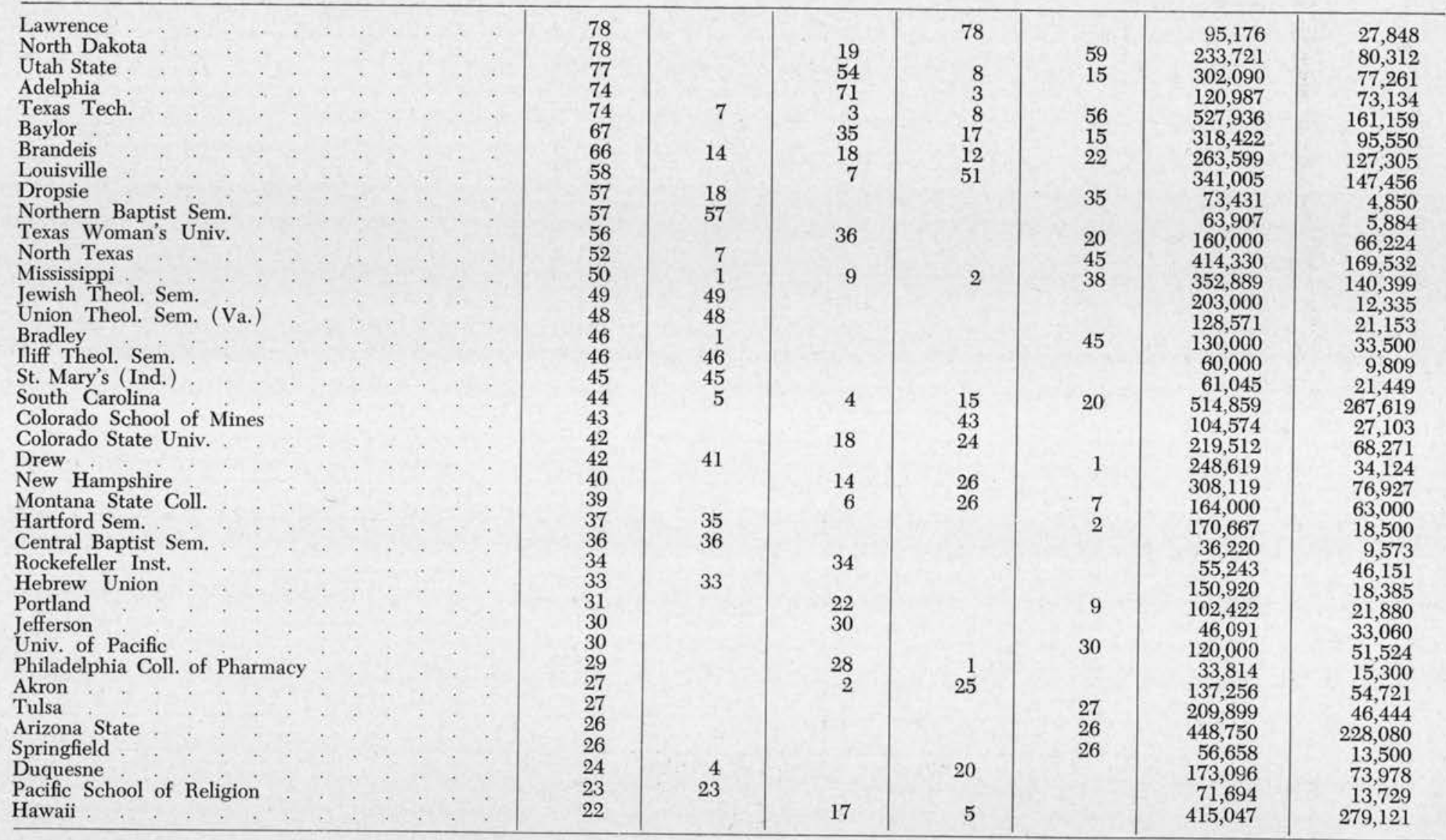


TABLE 1 (cont.)

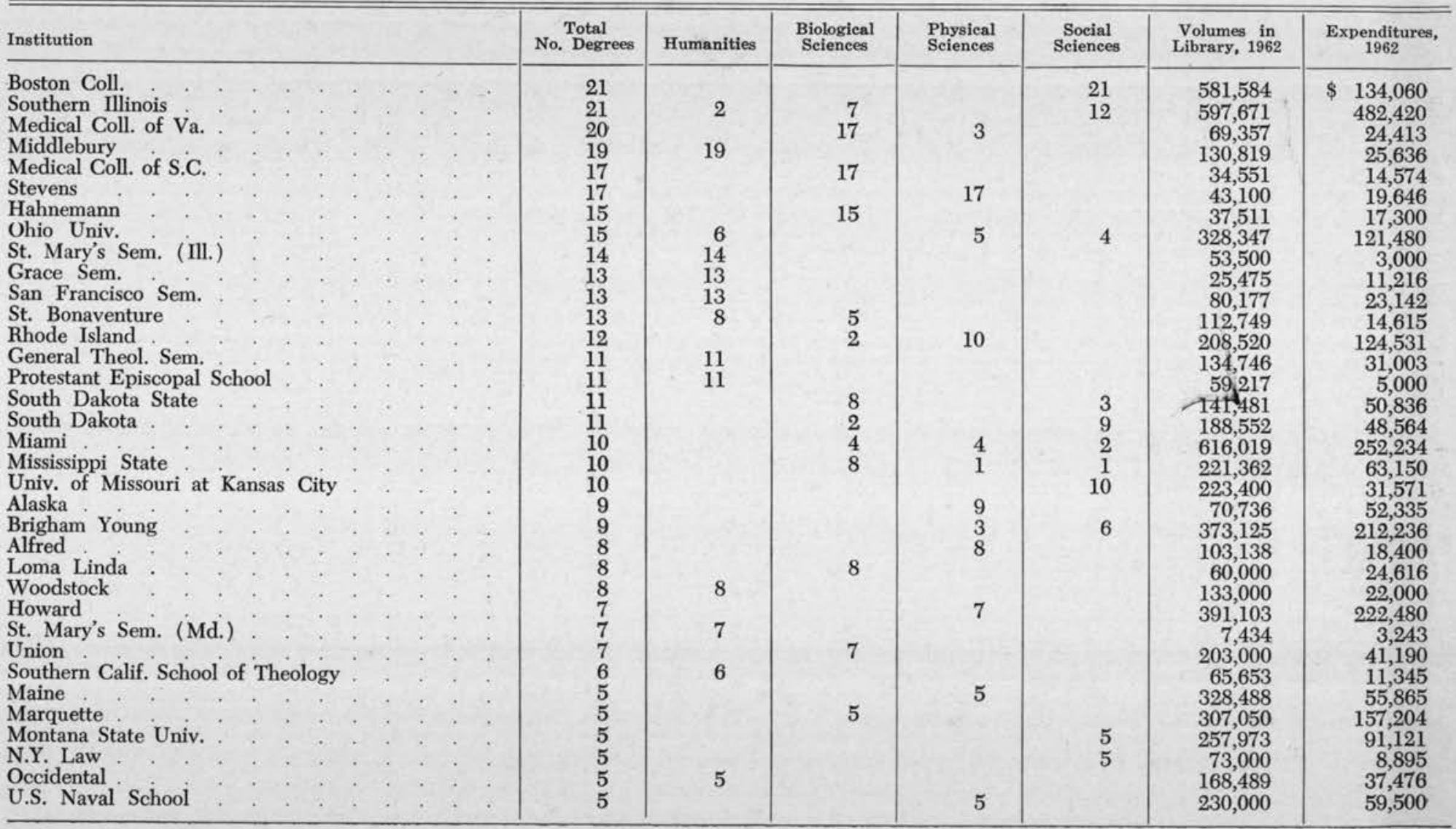


fornia's total for all of its campuses of $\$ 2,844,697$. Eleven universities reported expenditures in excess of $\$ 500,000$ each, nineteen between $\$ 300,000$ and $\$ 500,000$, and only eight less than $\$ 200,000$. Inflationary trends of the past several years have increased the totals; in 1963-64, twenty-eight universities spent more than $\$ 500,000$ for books and six exceeded $\$ 1$,000,000 .

Since there are no established norms, exactly how many volumes should be held by the library and how much money spent for books in an institution offering doctoral programs are debatable matters. Pragmatically speaking, however, it seems doubtful that high-level doctoral work in a variety of fields can be carried on with less than half a million volumes and with annual book expenditures under $\$ 200,000$. Applying these criteria to the 186 institutions included in the present investigation, only sixty-four met the 500,000 volume standard, and fifty-seven spent more than $\$ 200,000$ for library resources.

If these recommended, admittedly arbitrary levels are valid, 123 institutions were substandard in volume holdings and 130 in expenditures for library materials, as of 1962 .

In certain instances, there may have been mitigating facts. The specialized technical institutions-California Institute of Technology, Carnegie Institute of Technology, Brooklyn Polytechnic Institute, Illinois Institute of Technology, Rensselaer Polytechnic Institute, Case Institute of Technology, Colorado School of Mines, etc.-rank high academically, but their doctoral offerings are in a limited number of scientific and technical fields. Hence, their library requirements are considerably less varied than are those of general universities dealing with humanities and social sciences, as well as with science and technology. Such institutions as Purdue, Iowa State University, Pennsylvania State Univer- sity, and others which in the past have specialized in agriculture and engineering have grown slowly for the same reason, although in recent years they have tended to develop into comprehensive universities.

It should also be pointed out that Massachusetts Institute of Technology, which by general consent ranks at the top of this type of institution, possesses a library approaching a million volumes in size.

Another consideration that has doubtless influenced the modest size of libraries in certain doctoral-degree granting institutions is the proximity of extensive resources in other libraries. Examples are Bryn Mawr College in Philadelphia, closely allied to the University of Pennsylvania, and Radcliffe College in Cambridge, with its Harvard University affiliation. Unless there is a direct official connection, however, no university worthy of the name would expect to rely chiefly upon other institutions to provide the library resources needed by its doctoral candidates.

The most severe limitations of library collections and support found in the group granting doctoral degrees were among theological seminaries. The tradition that Christianity and Judaism are bookish religions is hardly borne out by the miniscule libraries and parsimonious book budgets which seem to be the rule rather than the exception in divinity schools. Two highly regarded institutions, Princeton Theological Seminary and Union Theological Seminary of New York, for example, expended $\$ 26,269$ and $\$ 25,486$, respectively, for library materials in 1961-62, and others ranged as low as $\$ 3,243$. Yet the twenty-two independent schools of this character awarded more than one thousand one hundred doctoral degrees in the period under review.

In summary, statistics of doctoral de(Continued on page 141) 
and Research Center, Inc., 117 R. Street N.E. Washington, D.C. 20002. v. 1, no. 1, May 1965. Bimonthly. \$7.25. 659916.

-Neuroendocrinology. S. Karger AG, Arnold-Bocklin-Strasse 25, 4000 Basel, Switzerland. v. 1 , no. $1,1965 / 66$. Bimonthly. $\$ 15.50$. 65-9943.

Northwest Folklore. University of Oregon Publications, Friendly Hall, Eugene, Ore. v. 1, no. 1, Summer 1965. Semiannual. $\$ 2.50 .65-9944$.

Palaeogeography, Palaeoclimatology, Palaeocology. Elsevier Publishing Company, P.O. Box 211, Amsterdam, The Netherlands. v. 1 , no. 1 , Mar. 1965 . 4 no. a year. \$14. 65-9956.

Private Pilot. Gallant Publishing Company, 550A S. Citrus Ave., Covina, Calif. v. 1, no. 1 , Oct./Nov. 1965. Bimonthly. \$3.25. 65-9949.

Religious Studies. Cambridge University Press, American Branch, 32 East 57th St., New York 10022. v. 1, no. 1, Oct. 1965. Semiannual. \$9.50. 65-9981.

Revista Latinoamericana de Sociología. Administración, Revista Latinoamericana de Sociología, Virrey del Pino 3230, Buenos Aires, Argentina. v. 1, no. 1, Mar. 1965. 3 no. a year. \$5. 65-9972.

School Safety. National Safety Council, Editorial and Executive Office, 425 North Michigan Ave., Chicago 60611. v. 1, no. 1, Sept./Oct. 1965. 4 no. a year. $\$ 3.60$. 65-9945.

Sci-Tech Book Profiles. R. R. Bowker Co., 1180 Avenue of the Americas, New York 10036. v. 1, no. 1, Aug. 1965. Monthly. Price not given. 65-9955.

Science Books; a Quarterly Review. Science Books, American Association for the Advancement of Science, 1515 Massachusetts Ave. N.W., Washington, D.C. 20005. v. 1, no. 1, Apr. 1965. Quarterly. $\$ 4.50 .65-9914$.

Southern Education Report. Southern Education Reporting Service, P.O. Box 6156, Nashville, Tenn. 37212 . v. 1, no. 1, July/ Aug. 1965. Bimonthly. \$2. 65-9938.

Syn; International Contributions to the New Art. Agis Verlag, 757 Baden-Baden, Lichtentaler Allee 84. 1, 1965. 3 no. a year. DM 36-. 65-9971.

Systems and Communications. Systems Publications Ltd., Bugle House, 2la Noel St.,
London W.1. v. 1, no. 1, Sept. 1965. Monthly. \$11 (free to certain categories of subscriber). 65-9946.

Theatre Design \& Technology. 1117 C.L., 4200 5th Ave. Pittsburgh 15213. no. 1, May 1965. 4 no. a year. \$6. 65-9932.

Urban Affairs Quarterly. Sage Publications Inc., 150 Fifth Ave., New York 10011. v. 1, no. 1, Sept. 1965. Quarterly. \$12. 65-9957.

View; the Magazine of Closed-Circuit and Community Antenna TV. RT Publishing Co., 10 Poplar Road, Ridgefield, Conn. 06877. v. 1, no. 1, Aug. 1965. Bimonthly. \$6. 65-9970.

Vista. United Nations Association of the United States of America Inc., 345 East 46th St., New York 10017. v. 1, no. 1, July/Aug. 1965. Bimonthly. Price not given. 65-9924.

Voices; the Art and Science of Psychotherapy. Alexander Jasnow, Managing Editor, 14-11 Lucena Drive, Fair Lawn, N.J. 07410. v. 1, no. 1, Fall 1965. Quarterly. \$8. 65-9947.

Voyageur. Box 5226 Powderhorn Station, Minneapolis, Minn. 55407. v. 1, no. 1, 1965. Semiannual. $\$ 2$ (per issue). 659939.

Weekly Compilation of Presidental Documents. Superintendent of Documents, U.S. Government Printing Office, Washington, D.C. 20402. v. 1, no. 1, Aug. 2, 1965. Weekly. \$6. 65-9929.

\section{DOCTORAL PROGRAMS . . .}

(Continued from page 129)

grees granted and of library holdings and book expenditures strongly support the view that the two go hand in hand in universities distinguished for their doctoral programs. An institution outstanding for its graduate offerings is almost invariably equally notable for the strength of its library resources. It is perhaps equally obvious that a substantial number of institutions giving the doctorate lack the library resources to support advanced-level graduate study, and should either discontinue such offerings or undertake extensive development of their libraries. 